\title{
Paediatric Cancer Predisposition Documentation Tool - Standardized Reporting Form for Children and Adolescents With Suspected Cancer Predisposition Syndrome
}

\author{
Ines B. Brecht
}

University Children's Hospital Tuebingen

Juliane Hoyer

Friedrich- Alexander University Erlangen-Nuremberg https://orcid.org/0000-0002-9368-0767

Tim Ripperger

Hannover Medical School

\section{Axel Karow}

University of Erlangen Nuremberg - Nuremberg Campus: Friedrich-Alexander-Universitat Erlangen-

Nurnberg - Campus Nurnberg

Arndt Borkhardt

Heinrich Heine University Düsseldorf: Heinrich-Heine-Universitat Dusseldorf

Triantafyllia Brozou

Heinrich-Heine-Universität Düsseldorf: Heinrich-Heine-Universitat Dusseldorf

Gianni Cazzaniga

University of Milano-Bicocca

Martin Ebinger

University Children's Hospital Tuebingen

\section{Roula Farah}

\section{LAU Medical Center-Rizk Hospital}

\section{Susana García Obregón}

University of the Basque County UPV/EHU

Julia Hauer

University Hospital Carl Gustav Carus

\section{Ariana Kamawal}

University of Erlangen-Nuremberg

Geertruij te Kronnie

University of Padova

\section{Michaela Kuhlen}

University Children's Hospital Augsburg

Jelena Lazic 
University Children's Hospital Belgrade

\section{Olli Lohi}

Tampere University and Tampere University Hospital

\section{Ugur Özbek}

Acibadem University Faculty of Medicine: Acibadem Universitesi Tip Fakultesi

\section{Antonio Pérez-Martínez}

University Hospital La Paz Madrid

\section{Olaf Rieß}

University Hospital Tuebingen

\section{Dominik T. Schneider}

Clinic of Paediatrics Dortmund

\section{Martin Schrappe}

University Hospital Schleswig Holstein

\section{Christopher Schroeder}

University Hospital Tuebingen

\section{Stefanie Zimmermann}

Goethe-University Frankfurt

\section{Christian T. Thiel}

University of Erlangen-Nuremberg

\section{Evelin Schroeck}

Faculty of Medicine Carl Gustav Carus

\section{André Reis}

University of Erlangen-Nuremberg

\section{Brigitte Schlegelberger}

Hannover Medical School

\section{Markus Metzler ( $\triangle$ Markus.Metzler@uk-erlangen.de )}

University Hospital Erlangen, Department of Paediatrics https://orcid.org/0000-0002-4523-1676

\section{Research article}

Keywords: PERCEPT, Cancer Predisposition Syndromes, Paediatric Cancer, Questionnaire, Childhood Malignancies

Posted Date: August 5th, 2021

DOI: https://doi.org/10.21203/rs.3.rs-778644/v1

License: (c) (1) This work is licensed under a Creative Commons Attribution 4.0 International License. Read Full License 


\section{Abstract}

More comprehensive genetic diagnostics in children with cancer, enabled by modern sequencing techniques have shown that germline variants causing genetic cancer predisposition can be detected in an increasing proportion of patients. Many individuals carrying a predisposing germline variant exhibit distinct characteristics regarding family history, tumor type, age at manifestation and therapy toxicity. However, comprehensive phenotypic characterization and automated electronic documentation in searchable databases are essential to fully integrate genetic and clinical features. Therefore, we have developed a structured Paediatric Cancer Predisposition Tool - PERCEPT to facilitate more accurate documentation of even subtle clinical features of patients with or with suspected germline cancer predisposition or suspected germline cancer predisposition. It improves the comparability in multicentre studies and the automated recognition of phenotypic patterns in international searchable databases.

\section{Introduction}

Genetic testing in children and adolescents with malignant diseases for suspected genetic cancer predisposition syndromes, have revealed a previously clinically underestimated high proportion of individuals with constitutional genetic variants associated with an increased cancer risk [1-3]. Pathogenic germline variants leading to cancer susceptibility are reported in at least $8-10 \%$ of childhood cancer patients [4]. Patients with secondary malignancies, a family history of cancer, the occurrence of malignancies at an unusually young age, or rare or adult-type tumors are more likely to have an underlying genetic cancer predisposition syndrome (CPS) [5].

Up to now the approach to identify patients with CPS was based on the awareness of phenotypic findings and family history. In clinical routine, the work-up of newly diagnosed cancer patients focuses on imminent medical challenges and prompt initiation of therapy, deferring from comprehensive phenotypic evaluation. In addition, clinical oncologists often do not have the training and expertise to recognize subtle morphological findings and standard phenotypic traits [6, 7]. Moreover, in contrast to the presentation of hereditary cancer predisposition syndromes with characteristic signs and inheritance [8], malignant diseases caused by germline variants also occur in a substantial number of individuals lacking a remarkable family history due to de-novo variants, incomplete penetrance, or variable expression of cancer susceptibility genes [9].

So far the bottle neck towards comprehensively uncovering individuals affected by a CPS was the lack of systematic genetic germline screening of all children and adolescents with malignancies. Meanwhile technological advances have significantly reduced the cost and turnover time of gene panel screening, whole exome and whole genome analysis enabling the identification of pathogenic germline variants in an increasing number of patients. There fore systematic clinical assessment and phenotypical description of individuals with suspected or confirmed pathogenic germline variants becomes more and more important. 
The "Paediatric Cancer Predisposition Documentation Tool" (PERCEPT) presented here has been developed as an additional tool for paediatric oncologists and medical geneticists. PERCEPT is a secondline instrument to be applied after identification of childhood cancer patients with suspected or confirmed cancer predisposing germline variants. It aims to serve as a tool for the systematic assessment and documentation of clinical characteristics. It will raise awareness in clinicians regarding syndromic features and would enable harmonized future studies in the field. This is the joint work of members of the CPS WG of the GPOH, SIOPE's Host Genome Working Group, the I-BFM Host Genetic Variation Working Group, the Working Group Tumor Genetics of the German Society of Human Genetics and the COST Action CA16223 "LEukaemia GENe Discovery by data sharing, mining and collaboration (LEGEND)".

\section{Methods And Results}

\section{Questionnaire development}

Documentation forms and questionnaires previously used for genetic counseling at participating institutions were collected and reviewed. The existing questionnaires mainly aimed to record and describe growth disorders, intellectual disability, or other congenital anomalies depending on the clinical and scientific focus of the respective institutions. The structures of the existing questionnaires were largely retained, but specific contents regarding predisposition syndromes for paediatric cancers were systematically included. To cover all the facets relevant to cancer predisposition syndromes, additional features and questions were identified by two approaches. First, features of currently known and well described cancer predisposition syndromes were added in the PERCEPT form. Second, characteristics of malignancies commonly associated with predisposing syndromes were also systematically integrated using Human Phenotype Ontology (HPO; http://human-phenotype-ontology.github.io/) terms exclusively throughout the form.

As described above, the PERCEPT form is not intended for patient identification and description in firstline clinical care, but is to be applied in a second step for a more comprehensive characterisation of individuals with CPS. A first-line selection tool was primarly described by Jongmans et al. [10] and later updated by Ripperger et al. [11]. The latter became an essential screening tool for GPOH trials and is a mandatory prerequisite for certification by the German Cancer Foundation [11]. The screening tool is intended to aid paediatric oncologists in identifying children with malignancies who may have a possible underlying cancer predisposition syndrome. In contrast, our Pediatric Cancer Predisposition Documentation Tool is designed for characterisation of children and adolescents with a malignant disease within or after diagnostic workup.

\section{Genetic medical counseling}

Genetic consultation and specific diagnosis should be conducted by specially trained physicians. In most institutions, including ours, this task is mainly performed by physician geneticists. However, in some countries genetic counselling is performed by physicians with alternative specialization. To allow the 
comparison of results from different countries in multicentre data collections, documentation of the qualification of the person responsible for PERCEPT assessment has been added.

\section{Current malignancy}

The current malignancy records include age at onset, occurrence of metastases, multiple primary tumors, unusual therapy toxicity, and presence of any molecular aberration indicative of a cancer predisposition syndrome. An unusually young age may be as important as the specific type of malignancy observed. The occurrence of adult-type tumors like gastrointestinal carcinomas, melanomas, malignancies of head and neck, lung cancer, and breast cancers is extremely rare in children. The aetiology is very likely to be different in children compared to adults (e.g. long-term exposure to toxins can be largely excluded). Information regarding the type of therapy and unusual therapy toxicity potentially associated with the germline aberration, are also included in PERCEPT. For instance, excessive toxicities have been observed in Fanconi anaemia patients after regular conditioning regimen before haematopoietic stem cell transplantation [12]. Also, patients with other DNA repair disorders or immune deficiencies may suffer from severe treatment complications [13].

\section{Previous malignancies}

Currently, nearly one out of five cancer cases occurs in individuals with a history of cancer. Within the cohort of individuals who suffered from childhood cancer, 9.3\% develop a secondary cancer within the following 30 years [14]. Carriers of germline variants in a certain cancer-predisposing gene are at higher risk of encountering another cancer. However, the appearance of secondary malignancies may also be attributed to the mutagenic effects of chemotherapy (mainly seen in leukaemia and myelodysplastic syndrome) and/or radiotherapy (mainly thyroid cancers, sarcomas, and brain tumors) [15]. The latency between the end of therapy and diagnosis of a secondary solid tumor is typically over 10 years whereas secondary leukaemia often occurs within few years after the primary disease. However, the effect of previous therapy on the development of a second malignancy is difficult to determine [16]. Another pitfall includes the observation that a wide range of therapy-induced cancers belongs to the spectrum of hereditary cancer predisposing syndromes. Moreover, it is well established that individuals with certain hereditary disorders have increased sensitivity to the carcinogenic effects of therapies, such as DNA damage repair, oxidative stress, and cell cycle control, which likely contributes to the development of radiation- and chemotherapy-related cancers.

\section{Pregnancy / Birth}

Pregnancy, birth, and neonatal history are captured in PERCEPT to document growth retardation or overgrowth. To assess if the patient's phenotypic signs belong to a certain cancer predisposition syndrome or can be partially attributed to other factors, additional points, including infections or exposure to toxic agents during pregnancy, are recorded.

\section{Medical history / Clinical examination}


PERCEPT also allows recording the medical history of the patient, including early childhood development and results of clinical examinations. Cancer predisposing syndromes can be associated with developmental anomalies and skin lesions, such as café-au-lait-spots in neurofibromatosis type I, Constitutional Mismatch Repair Deficiancy (CMMRD) or Fanconi anemia. However, in most cases, symptoms are subtle and vague, and only all full description of abnormalities might shed light on the complete picture of the signs and symptoms associated with a certain CPS.

\section{Dysmorphological abnormalities}

A comprehensive literature review and database search (PubMed; OMIM, http://www.omim.org; Genereviews, https://www.ncbi.nlm.nih.gov/books/NBK1116/; Genetics Home Reference, https://ghr.nlm.nih.gov/) was performed to collect common congenital anomalies and characteristic physical findings associated with known cancer predisposition syndromes [11, 17]. All morphological anomalies have been sorted by organ system; examples are shown in Table 1.

While several cancer predisposition syndromes, such as Down syndrome and Beckwith-Wiedemann syndrome, are already well described and associated with characteristic dysmorphological signs, others are associated only with minor morphological signs (8). The relation between minor anomalies and childhood cancers, especially solid tumors is well documented. Moreover, it has been shown that genes entangled in organogenesis may cause minor congenital anomalies and may be involved in the development of cancer [18]. Thus, it becomes important to identify the complete spectrum of physical findings and possible congenital and developmental abnormalities while also accounting for the possibility of altered prevalence with age. Congenital anomalies and physical findings not explained by an underlying cancer predisposition syndrome might be due to an unknown syndrome not discovered till now or could be due to another unrelated condition which does not predispose to cancer. In addition, PERCEPT specifically documents external factors (infection, teratogen and other) to capture differential diagnoses with acquired aetiology.

\section{Previous examinations}

The chapter "previous examinations" refers to previous genetic counselling and testing conducted. Until recently, genetic analyses were focused on specific genes based on syndromic features and family history, as well as chromosome analyses and Sanger Sequencing. However, the focus has now shifted to next generation sequencing methods that made comprehensive genetic testing feasible.

This chapter also includes genetic analysis of tumors, primarily looking for somatic variants, with possible impacts on diagnosis, prognosis and therapy. These analyses may also reveal a suspicion for a germline pathogenic variant, e.g. in $\operatorname{TP53}$ or $\operatorname{IKZF1}[15,19]$.

Imaging performed previously can add to syndromic features found in clinical examinations as some symptoms and signs are only detectable by instrument-based investigations (e.g. radiography). Examples include malformations of bones, cysts of organs, benign tumors, malrotation of organs.

\section{Family history}


Family history and guidelines to generate a family tree are included in PERCEPT. While collecting information regarding cancer history, information on all childhood- and adult-onset malignancies, age at onset, and type and site of each malignancy up to third-degree relatives should be included. Inherited pathogenic variants can be accompanied by different degrees of penetrance and can cause cancer in childhood and/or adulthood leading to different disease presentations. Any cases of death with unknown cause in the family, along with age at the time of death, should be included. Furthermore, diseases like immunodeficiency and other congenital disorders, as well as family members with mental retardation or syndromic features, should be annotated and clinical reports, pathology reports, and any pre-existing genetic analyses for family members should be collected.

While assessing information on families with certain tumor syndromes, an unusually young age at cancer diagnosis may be as important as the specific type of malignancy observed. The occurrence of adult-type tumors, such as gastrointestinal carcinomas, melanomas, malignancies of head and neck, lung cancers, and breast cancers is extremely rare in children.

\section{Family tree}

A common pedigree nomenclature is mandatory to allow for a standard inheritance assessment. We followed the nomenclature published by the National Cancer Institute (https://visualsonline.cancer.gov/details.cfm?imageid=10346). Because cancer predisposition syndromes mainly follow an autosomal dominant pattern of inheritance, the occurrence of several malignancies in a family is particularly indicative of a cancer predisposition syndrome running in a family. However, the presence is not excluded if the index patient is the only known case as there are other modes of inheritance as well, which include rare autosomal recessive, $\mathrm{X}$-linked recessive or more complex inheritance modes (e.g. methylation dependent disorders).

In contrast, no or low frequency of malignancies in a family can be indicative of de novo pathogenic variants, incomplete penetrance, or related to small family size. Moreover, in cases of autosomal recessive cancer predisposition syndromes, the parents are carriers and the family tree is most likely unremarkable. In such cases, a possible consanguinity between parents or in the family would be of relevance.

\section{Discussion}

Due to the rapid technical advances in sequencing methods in the recent years, the number of patients diagnosed with malignant diseases in childhood and adolescence who carry a disease causing germline variant has increased significantly. This has also increased the clinical attention for these individuals because these conditions are now perceived as a more frequent diagnosis with sometimes subtle manifestations.

This in turn highlights the demand for a suitable routine procedure to characterize and follow-up patients with malignant diseases that have a high likelihood of having a CPS with consequences for cancer 
treatment and long-term surveillance. In the past, easy-to-use selection tools based on family history, type of malignancy, number of malignancies in the same patient, some basic congenital anomalies, and other specific features and excessive toxicity were used in the process of reliable identification of candidates for further genetic assessment in daily routine $[10,11]$.

The intention of PERCEPT was to extend this structured procedure by generating a tool for standardized documentation of targeted anamnesis and comprehensive phenotypic description. This information may prove useful in two directions. First, to ensure detailed clinical characterisation and documentation of individuals with defined genetic variants in searchable databases; and second, to improve the development of automated tools for the detection of cancer predisposition syndromes based on clinical features. Thus, it is important to identify the complete spectrum of physical findings and developmental abnormalities and relate them to patient age as there might be an increased or decreased prevalence with age. Therefore the systematic recording of clinical features at the time of tumor diagnosis is needed, when the full picture of the underlying syndrome might not be completely obvious and re-evaluation needs to be scheduled. This proceeding may provide a relevant source for expanding the phenotype of CPS and contribute novel findings to the underlying development of cancer.

Moreover, identifying and understanding links between congenital abnormalities, childhood development and the risk of developing cancer will have impact for risk estimation, surveillance, prognosis, families and potential personalized therapies.

International co-operation within SIOPE (https://siope.eu/) and COST (https://www.cost.eu/) has contributed significantly to the formulation of a series of surveillance recommendations and the discovery of novel gene variants in familial and syndromic malignancies. The different structural and organizational requirements in the participating countries have been considered while designing PERCEPT. The format of the PERCEPT form is easy to implement into electronic data capture and supports the analysis of genetic information in conjunction with clinical features in multicentre, international studies.

Especially because the future perspective might be genetic testing of all pediatric patients diagnosed with malignant diseases in childhood and adolescence $[3,20]$, a comprehensive and standardized phenotypic description of individuals with childhood malignancies is mandatory for the comprehensive interpretation of genetic data and comparison between different study cohorts. We hope that PERCEPT might serve as a useful tool to improve standardized documentation and educate and train doctors who are engaged in the field of cancer predisposition syndromes. In view of the constant growth of knowledge in this field, it is obvious that the contents of PERCEPT must be constantly amended.

\section{Declarations}

\section{Funding}


COSTAction CA16223 LEukaemia GENe Discovery by datasharing, mining, and collaboration (LEGEND) is supported by the EU Framework Programme Horizon 2020.

\section{Conflicts of interest/Competing interests}

Olaf Rieß reports research support from Illumina and institutional research support from Novartis. Christopher Schroeder reports research support from Illumina, Stiftung Immunonkologie (BMS) and institutional research support from Novartis. Ines Brecht received research support from Illumina.

All other authors declare no conflict of interest.

\section{Ethics approval}

Not applicable

\section{Consent to participate}

Not applicable

\section{Consent for publication}

Not applicable

\section{Availability of data and material}

All data are included in the manuscript

\section{Code availability}

Not applicable

\section{Acknowledgements}

Ines Brecht received a fellowship from the Madeleine Schickedanz Foundation. Brigitte Schlegelberger is participating in the European Reference Network for paediatric oncology (ERN-PaeDCan). Brigitte Schlegelberger and Evelin Schrock are participating in the European Reference Network for all patients with one of the rare genetic tumor risk syndromes (ERN-GENTURIS).

\section{References}

1. Kuhlen M, Borkhardt A. Cancer susceptibility syndromes in children in the area of broad clinical use of massive parallel sequencing. European journal of pediatrics. 2015;174(8):987-97.

2. Parsons DW, Roy A, Yang Y, Wang T, Scollon S, Bergstrom K, et al. Diagnostic Yield of Clinical Tumor and Germline Whole-Exome Sequencing for Children With Solid Tumors. JAMA Oncol. 2016;2(5):61624. 
3. American Society of Clinical O. American Society of Clinical Oncology policy statement update: genetic testing for cancer susceptibility. Journal of clinical oncology : official journal of the American Society of Clinical Oncology. 2003;21(12):2397-406.

4. Zhang J, Walsh MF, Wu G, Edmonson MN, Gruber TA, Easton J, et al. Germline Mutations in Predisposition Genes in Pediatric Cancer. The New England journal of medicine. 2015;373(24):233646.

5. Mody RJ, Wu YM, Lonigro RJ, Cao X, Roychowdhury S, Vats P, et al. Integrative Clinical Sequencing in the Management of Refractory or Relapsed Cancer in Youth. JAMA. 2015;314(9):913-25.

6. Merks JH, Caron HN, Hennekam RC. High incidence of malformation syndromes in a series of 1,073 children with cancer. Am J Med Genet A. 2005;134A(2):132-43.

7. Merks JH, Ozgen HM, Koster J, Zwinderman AH, Caron HN, Hennekam RC. Prevalence and patterns of morphological abnormalities in patients with childhood cancer. JAMA. 2008;299(1):61-9.

8. Garber JE, Offit K. Hereditary cancer predisposition syndromes. Journal of clinical oncology : official journal of the American Society of Clinical Oncology. 2005;23(2):276-92.

9. Malkin D, Nichols KE, Zelley K, Schiffman JD. Predisposition to pediatric and hematologic cancers: a moving target. American Society of Clinical Oncology educational book / ASCO American Society of Clinical Oncology Meeting. 2014:e44-55.

10. Jongmans MC, Loeffen JL, Waanders E, Hoogerbrugge PM, Ligtenberg MJ, Kuiper RP, et al. Recognition of genetic predisposition in pediatric cancer patients: An easy-to-use selection tool. Eur $\mathrm{J}$ Med Genet. 2016;59(3):116-25.

11. Ripperger T, Bielack SS, Borkhardt A, Brecht IB, Burkhardt B, Calaminus G, et al. Childhood cancer predisposition syndromes-A concise review and recommendations by the Cancer Predisposition Working Group of the Society for Pediatric Oncology and Hematology. Am J Med Genet A. 2017;173(4):1017-37.

12. Peffault de Latour R, Porcher R, Dalle JH, Aljurf M, Korthof ET, Svahn J, et al. Allogeneic hematopoietic stem cell transplantation in Fanconi anemia: the European Group for Blood and Marrow Transplantation experience. Blood. 2013;122(26):4279-86.

13. Bienemann K, Burkhardt B, Modlich S, Meyer U, Moricke A, Bienemann K, et al. Promising therapy results for lymphoid malignancies in children with chromosomal breakage syndromes (Ataxia teleangiectasia or Nijmegen-breakage syndrome): a retrospective survey. $\mathrm{Br} \mathrm{J}$ Haematol. 2011;155(4):468-76.

14. Meadows AT, Friedman DL, Neglia JP, Mertens AC, Donaldson SS, Stovall M, et al. Second neoplasms in survivors of childhood cancer: findings from the Childhood Cancer Survivor Study cohort. Journal of clinical oncology : official journal of the American Society of Clinical Oncology. 2009;27(14):235662.

15. Parsons DW, Roy A, Yang Y, Wang T, Scollon S, Bergstrom K, et al. Diagnostic Yield of Clinical Tumor and Germline Whole-Exome Sequencing for Children With Solid Tumors. JAMA Oncol. 2016. 
16. Bhatia S, Sklar C. Second cancers in survivors of childhood cancer. Nat Rev Cancer. 2002;2(2):12432.

17. Merks JHM, Brecht IB. Genetic Predisposition and Genetic Susceptibility. Schneider DT, Brecht IB, Olson TA, Ferrari A, editors. Berlin Heidelberg: Springer; 2012.

18. Narod SA, Hawkins MM, Robertson CM, Stiller CA. Congenital anomalies and childhood cancer in Great Britain. Am J Hum Genet. 1997;60(3):474-85.

19. Churchman ML, Qian M, Te Kronnie G, Zhang R, Yang W, Zhang H, et al. Germline Genetic IKZF1 Variation and Predisposition to Childhood Acute Lymphoblastic Leukemia. Cancer Cell. 2018;33(5):937-48 e8.

20. Kuhlen M, Taeubner J, Brozou T, Wieczorek D, Siebert R, Borkhardt A. Family-based germline sequencing in children with cancer. Oncogene. 2019;38(9):1367-80.

\section{Table}

Supplemental Table 1: Cancer predisposition syndromes frequently observed in children and associated morphological abnormalities 
Syndrome/ Gene

APC-Associated Polyposis Conditions

(FAP, Gardner`s syndrome, Turcot syndrome)

APC
Non-malignant clinical features

- Colonic polyps (beginning at an age of

16 years on average)

- Polyps of the gastric fundus and duodenum

- Osteomas

- Dental anomalies

- Congenital hypertrophy of the retinal

pigment epithelium (CHRPE)

- Benign thyroid disease

- Benign cutaneous lesions including

epidermoid cysts or desmoid tumours
Malignancies reported

- Medulloblastoma

- Hepatoblastoma

- Small bowel/ Colon

carcinoma

- Pancreatic-cancer

- Papillary thyroid

carcinoma

- Adenocarcinoma of

stomach or bile ducts
Ataxia telangiectasia

ATM

- Progressive cerebellar ataxia (beginning

between age of 1-4 years)

- Progressively slurred speech

- Choreoathetosis

- Oculomotor apraxia

- Oculocutaneous telangiectasia

- Immunodeficiency with frequent infections

- Premature aging with strands of grey hair

- Endocrine abnormalities

Baller-Gerold syndrome RECQL4
- Coronal craniosynostosis

- Brachycephaly with ocular proptosis and

prominent forehead

- Radial ray defect

- Short stature

- Poikiloderma

Beckwith-Wiedemann

syndrome

Aberrant methylation on

the maternal chromosome

at imprinting loci 1 or 2

Paternal uniparental

disomy for chromosome

$11 \mathrm{p} 15$

Maternally inherited

pathogenic variant in

CDKN1C
- Neonatal hypoglycaemia

- Macrosomia

- Macroglossia

- Hemihypertrophy (asymmetric)

- Omphalocele, umbilical hernia

- Visceromegaly

- Renal abnormalities

- Ear creases/ Pits of the helices

- Cytomegaly of the foetal adrenal cortex

(pathognomonic)
- ALL/ T-cell leukaemia

- (B-cell) Lymphoma

- Breast cancer

- Gastric cancer

- Melanoma

- Leiomyoma

- Sarcoma

- Osteosarcoma

- Lymphoma

- Skin Cancer
Bloom syndrome

BLM
- Intrauterine growth deficiency, persisting

into infancy, childhood, adulthood

- Erythematous skin lesion after sun

exposure on the face

- Teleangiectases of the skin

- Hyper/Hypopigmentation of the skin

- Gastroesophageal reflux (GER)

- Infections of upper respiratory tract/

middle ear/ lung

- Learning disability

- Chronic obstructive pulmonary disease

- Loss of the lower eyelashes and blister

and fissures of the lower lip
- ALL/ AML

- Lymphoma

- MDS

- Germ-cell tumour

- Retinoblastoma

- Brain tumour

- Sarcoma

- Epithelial carcinomas

- CUP syndrome 


\begin{tabular}{|c|c|c|}
\hline Syndrome/ Gene & Non-malignant clinical features & Malignancies reported \\
\hline $\begin{array}{l}\text { Bohring -Opitz syndrome } \\
\text { ASXL1 }\end{array}$ & $\begin{array}{l}\text { - Intrauterine growth retardation } \\
\text { - Severe Mental retardation } \\
\text { - Seizures } \\
\text { - Trigonocephaly } \\
\text { - Prominent metopic suture } \\
\text { - Exophthalmos } \\
\text { - Frontal nevus flammeus } \\
\text { - Flexion deformities of upper limbs }\end{array}$ & $\begin{array}{l}\text { - Bilateral Wilms } \\
\text { tumour }\end{array}$ \\
\hline $\begin{array}{l}\text { Costello syndrome } \\
\text { HRAS }\end{array}$ & $\begin{array}{l}\text { - Short stature } \\
\text { - Postnatal feeding difficulties } \\
\text { - Coarse facial features } \\
\text { - Curly or sparse, fine hair, soft skin } \\
\text { - Joint laxity } \\
\text { - Developmental disability } \\
\text { - Papillomata of the face and perianal } \\
\text { region; diffuse hypotonia and joint laxity } \\
\text { - Cardiac hypertrophy (esp. typical } \\
\text { hypertrophic cardiomyopathy } \\
\text { - Heart defect (esp. pulmonary valve } \\
\text { stenosis), } \\
\text { - Arrhythmia (esp. supraventricular } \\
\text { tachycardia). } \\
\text { - Relative or absolute macrocephaly } \\
\text { - Chiari malformation due to postnatal } \\
\text { cerebellar overgrowth }\end{array}$ & $\begin{array}{l}\text { - Solid tumours of early } \\
\text { childhood, } \\
\text { - Neuroblastoma } \\
\text { - Rhabdomyosarcoma } \\
\text { - Transitional cell } \\
\text { carcinoma of the } \\
\text { bladder in adolescents }\end{array}$ \\
\hline $\begin{array}{l}\text { CMMRD } \\
\text { MSH2, MSH6, MLH1, } \\
\text { PMS2 }\end{array}$ & $\begin{array}{l}\text { - Café au lait spots, axillar freckling } \\
\text { - Neurofibromas } \\
\text { - Colorectal polyps }\end{array}$ & $\begin{array}{l}\text { - brain tumors in } \\
\text { childhood } \\
\text { - leukemias in } \\
\text { childhood } \\
\text { - colorectal cancer in } \\
\text { the 2nd /3rd life } \\
\text { decade }\end{array}$ \\
\hline $\begin{array}{l}\text { Denys Drash Syndrome } \\
\text { WT1 }\end{array}$ & $\begin{array}{l}\text { - Genital abnormalities } \\
\text { (pseudohermaphroditism) } \\
\text { - Diffuse mesangial sclerosis leading to } \\
\text { early-onset renal failure }\end{array}$ & - Wilms tumour \\
\hline $\begin{array}{l}\text { Diamond Blackfan } \\
\text { Anaemia } \\
\text { RPL5, RPL 11, RPL35, } \\
\text { RPS10, RPS17, RPS19, } \\
\text { RPS24, RPS26 } \\
\text { GATA1, RPL 15, RPL26, } \\
\text { RPL27, RPL31, RPS7, } \\
\text { RPS27, RPS28, ROS29, } \\
\text { TSR2 }\end{array}$ & $\begin{array}{l}\text { - Normochromic macrocytic anaemia } \\
\text { - Pallor, weakness, failure to thrive } \\
\text { - Growth retardation } \\
\text { - Craniofacial, upper limb, heart and urinary } \\
\text { system malformations }\end{array}$ & $\begin{array}{l}\text { - } \mathrm{AML} \\
\text { - MDS } \\
\text { - Osteosarcoma } \\
\text { - Colon cancer }\end{array}$ \\
\hline
\end{tabular}




\section{Syndrome/ Gene}

DiGeorge syndrome

Deletion 22q11.2
Non-malignant clinical features

- Congenital heart disease (conotruncal malformations) (tetralogy of Fallot, interrupted aortic arch, ventricular septal defect, and truncus arteriosus)

- Palatal abnormalities (velopharyngeal incompetence, cleft palate)

- Characteristic facial features

- Learning difficulties

- Immune deficiency

- Short stature

- Hypocalcaemia

- Psychiatric illness

Down syndrome

Trisomy 21

- Short stature

- Short and wide neck
- Protruding, large tongue to a small mouth

- Epicanthic fold

- Upslanting palpebral fissures

- Flat nasal bridge

- Muscular hypotonia

- Joint flexibility

- Brachydactyly, Clinodactyly

- Sandal gap

- Transverse palmar crease

- Congenital malformations (heart, gastrointestinal tract)

- Moderate Mental retardation

- Immunodeficiency

Dyskeratosis congenita, X-linked

DKC1
- Reticulated skin pigmentation

- Nail dystrophy, leucoplakia of oral mucosa

- Short stature and microcephaly

- Pulmonary fibrosis

- Liver cirrhosis

- Premature hair loss and greying

- Osteoporosis

- Eye abnormalities

- Dental abnormalities (early tooth loss)

- Learning difficulties

- Genitourinary malformations

- Immunodeficiency with opportunistic infections
Malignancies reported

- Hepatoblastoma

- Renal cell carcinoma,

- Wilms tumour

- Neuroblastoma
- ALL

- AML
- MDS

- AML

- Solid tumour

- Squamous cell carcinoma (skin or mucosa)

- Hodgkin disease

- Pancreatic carcinoma
Fanconi Anaemia

Most common: BRCA2, BRIP1, FANCA, FANCB, FANCC, FANCD2, FANCE, FANCF, FANCG, FANCl; Less common: ERCC4, FANCL, FANCM, MAD2L2, PALB2, RAD51, RAD51C, RFWD3, SLX4, UBE2T, XRCC2
- Pancytopenia

- Short stature

- Abnormal skin pigmentation

- Skeletal malformations

- Radial aplasia/Thumb deformity

- Microcephaly

- Ophthalmic and genitourinary tract anomalies

- Mental retardation
- AML

- MDS

- Solid tumours, esp. head and neck squamous cell carcinomas (HNSCCs)

- Cancers in the skin and genitourinary tract
Frasier syndrome WT1
- Pseudohermaphroditism

- Focal segmental glomerulosclerosis
- Wilms tumour 


\begin{tabular}{|c|c|c|}
\hline Syndrome/ Gene & Non-malignant clinical features & Malignancies reported \\
\hline $\begin{array}{l}\text { Gorlin syndrome } \\
\text { PTCH2 } \\
\text { PTCH1 } \\
\text { SUFU }\end{array}$ & $\begin{array}{l}\text { - Multiple jaw keratocysts } \\
\text { - Lamellar calcification of the falx } \\
\text { - Palmar/plantar pits } \\
\text { - Cardiac and ovarian fibromas } \\
\text { - Macrocephaly } \\
\text { - Lympho-mesenteric or pleural cysts } \\
\text { - Cleft lip/palate } \\
\text { - Vertebral/rib anomalies } \\
\text { (bifid/splayed/extra ribs; bifid vertebrae) } \\
\text { - Preaxial or postaxial polydactyly } \\
\text { - Ocular anomalies (cataract, retinal } \\
\text { pigmentary changes) }\end{array}$ & $\begin{array}{l}\text { - Medulloblastoma } \\
\text { - Multiple basal cell } \\
\text { carcinomas (BCCs) }\end{array}$ \\
\hline $\begin{array}{l}\text { Hereditary multiple } \\
\text { exostoses } \\
\text { EXT1/2 }\end{array}$ & $\begin{array}{l}\text { - Multiple Osteochondromas } \\
\text { - Short stature } \\
\text { - Bony deformity } \\
\text { - Restricted joint motion } \\
\text { - Osteoarthrosis }\end{array}$ & Osteochondrosarcoma \\
\hline $\begin{array}{l}\text { Juvenile Polyposis } \\
\text { Syndrome } \\
\text { SMAD4 }\end{array}$ & $\begin{array}{l}\text { - hamartomatous polyps in the } \\
\text { gastrointestinal (GI) tract }\end{array}$ & $\begin{array}{l}\text { - colon cancer } \\
\text { - cancers of the } \\
\text { stomach and upper } \mathrm{GI} \\
\text { tract } \\
\text { - pancreatic cancer }\end{array}$ \\
\hline $\begin{array}{l}\text { Li-Fraumeni syndrome } \\
\text { TP53 }\end{array}$ & No specific clinical features & $\begin{array}{l}\text { - Soft tissue sarcoma } \\
\text { - Osteosarcoma } \\
\text { - Adrenocortical } \\
\text { carcinoma (ACC) } \\
\text { - Leukaemia } \\
\text { - Pre-menopausal } \\
\text { breast cancer } \\
\text { - Brain tumours } \\
\text { - Choroid plexus } \\
\text { carcinoma (CPC) } \\
\text { - Others }\end{array}$ \\
\hline $\begin{array}{l}\text { Multiple Endocrine } \\
\text { Neoplasia Type } 1 \\
\text { MEN1 }\end{array}$ & $\begin{array}{l}\text { - Facial angiofibromas. } \\
\text { - Collagenomas } \\
\text { - Lipomas } \\
\text { - Café-au-lait macules (CALMs) } \\
\text { - Confetti-like hypopigmented macules } \\
\text { - Multiple gingival papules - } \\
\text { - Meningioma }\end{array}$ & $\begin{array}{l}\text { - Parathyroid tumours } \\
\text { - Pituitary tumours } \\
\text { - Well-differentiated } \\
\text { endocrine tumours of } \\
\text { the gastro-entero- } \\
\text { pancreatic (GEP) tract } \\
\text { - Carcinoid tumours } \\
\text { - Adrenocortical } \\
\text { tumours } \\
\text { - Ependymoma }\end{array}$ \\
\hline $\begin{array}{l}\text { MEN2A } \\
\text { RET }\end{array}$ & No specific clinical features & $\begin{array}{l}\text { - Medullary thyroid } \\
\text { carcinoma (MTC) } \\
\text { - Pheochromocytoma } \\
\text { - Parathyroid } \\
\text { adenoma/hyperplasia. }\end{array}$ \\
\hline
\end{tabular}




\begin{tabular}{|c|c|c|}
\hline Syndrome/ Gene & Non-malignant clinical features & Malignancies reported \\
\hline $\begin{array}{l}\text { MEN2B } \\
\text { RET }\end{array}$ & $\begin{array}{l}\text { - Mucosal neuromas of lips and tongue } \\
\text { - Thick vermilion of the lips, } \\
\text { - Medullated corneal nerve fibres, } \\
\text { - Marfanoid habitus }\end{array}$ & $\begin{array}{l}\text { - Only medullary } \\
\text { thyroid carcinoma } \\
\text { (MTC) }\end{array}$ \\
\hline $\begin{array}{l}\text { FMTC } \\
\text { RET }\end{array}$ & No specific clinical features & $\begin{array}{l}\text { - Only medullary } \\
\text { thyroid carcinoma } \\
\text { (MTC) }\end{array}$ \\
\hline $\begin{array}{l}\text { Mulibrey nanism } \\
\text { TRIM37 }\end{array}$ & $\begin{array}{l}\text { - Short stature with prenatal onset } \\
\text { - Triangular face } \\
\text { - Congestive heart failure } \\
\text { - Weak, high-pitched voice } \\
\text { - Hepatomegaly } \\
\text { - Muscular hypotonia } \\
\text { - Large cerebral ventricles and cisterna }\end{array}$ & - Wilms tumour \\
\hline $\begin{array}{l}\text { Neurofibromatosis type } 1 \\
\text { NF1 }\end{array}$ & $\begin{array}{l}\text { - Multiple café-au-lait macules } \\
\text { - Axillary and inguinal freckling } \\
\text { - Multiple cutaneous neurofibromas/ } \\
\text { plexiform neurofibromas } \\
\text { - Iris Lisch nodules } \\
\text { - Learning disabilities } \\
\text { - Scoliosis } \\
\text { - Tibial dysplasia } \\
\text { - Hypertension, essential or due to renal } \\
\text { artery stenosis }\end{array}$ & $\begin{array}{l}\text { - Leukaemia } \\
\text { - (Optic nerve) Glioma } \\
\text { - Brain tumours } \\
\text { - Gastrointestinal } \\
\text { stromal tumours } \\
\text { - Retinal } \\
\text { vasoproliferative } \\
\text { tumours } \\
\text { - Breast cancer before } \\
\text { age } 50 \text { years in women } \\
\text { - Many other common } \\
\text { cancers } \\
\text { - Peripheral nerve } \\
\text { sheath tumour and } \\
\text { other soft tissue } \\
\text { sarcomas }\end{array}$ \\
\hline $\begin{array}{l}\text { Nijmegen breakage } \\
\text { syndrome } \\
\text { NBN }\end{array}$ & $\begin{array}{l}\text { - Disproportionate microcephaly } \\
\text { - Craniofacial features (sloping forehead, } \\
\text { prominent nose, retrognathia) } \\
\text { - Short stature } \\
\text { - Recurrent (sinopulmonary) infections } \\
\text { - Decline in intellectual ability } \\
\text { - Premature ovarian failure }\end{array}$ & $\begin{array}{l}\text { - Mainly lymphomas } \\
\text { - Solid tumours (for } \\
\text { instance } \\
\text { medulloblastoma, } \\
\text { glioma and } \\
\text { rhabdomyosarcoma) }\end{array}$ \\
\hline $\begin{array}{l}\text { Noonan syndrome } \\
\text { PTPN11, SOS1, RAF1, } \\
\text { RIT1, KRAS, NRAS, } \\
\text { BRAF, } \\
\text { MAP2KI }\end{array}$ & $\begin{array}{l}\text { - Short stature } \\
\text { - Congenital heart defects (esp. pulmonary } \\
\text { valve stenosis,) } \\
\text { - Hypertrophic cardiomyopathy } \\
\text { - (Mild) mental retardation } \\
\text { - Facial dysmorphism } \\
\text { - broad neck, unusual chest shape } \\
\text { - Cryptorchidism } \\
\text { - Bleeding diathesis } \\
\text { - Lymphatic dysplasia }\end{array}$ & $\begin{array}{l}\text { - Juvenile } \\
\text { myelomonocytic } \\
\text { leukaemia (JMML) } \\
\text { - ALL } \\
\text { - AML } \\
\text { - Solid tumours (such } \\
\text { as rhabdomyosarcoma } \\
\text { and neuroblastoma) }\end{array}$ \\
\hline
\end{tabular}




\begin{tabular}{|c|c|c|}
\hline Syndrome/ Gene & Non-malignant clinical features & Malignancies reported \\
\hline $\begin{array}{l}\text { Perlman syndrome } \\
\text { DIS3L2 }\end{array}$ & $\begin{array}{l}\text { - Congenital Macrosomia } \\
\text { - Visceromegaly } \\
\text { - Facial Dysmorphism (prominent forehead, } \\
\text { depressed nasal bridge, anteverted upper } \\
\text { lip) } \\
\text { - Bilateral renal hamartomas / } \\
\text { Nephroblastomatosis } \\
\text { - Hyperinsulinism }\end{array}$ & -Wilms tumour \\
\hline $\begin{array}{l}\text { Peutz-Jeghers syndrome } \\
\text { STK11 }\end{array}$ & $\begin{array}{l}\text { - Melanocytic macules of the lips, buccal } \\
\text { mucosa and digits } \\
\text { - Multiple gastrointestinal/ extraintestinal } \\
\text { hamartomatous polyps } \\
\text { - Sex cord tumours with annular tubules } \\
\text { (SCTAT) }\end{array}$ & $\begin{array}{l}\text { Epithelial } \\
\text { malignancies: } \\
\text { - Colorectal carcinoma } \\
\text { - Gastric carcinoma } \\
\text { - Pancreatic cancer } \\
\text { - Mamma carcinoma } \\
\text { - Ovarian carcinoma } \\
\text { - Adenoma malignum } \\
\text { of the cervix }\end{array}$ \\
\hline $\begin{array}{l}\text { PTEN-Hamartoma-Tumor- } \\
\text { Syndrom (PHTS) } \\
\text { PTEN }\end{array}$ & $\begin{array}{l}\text { - Benign breast disease } \\
\text { - Multinodular goiter } \\
\text { - Benign uterine fibroids } \\
\text { - Macrocephaly } \\
\text { - Trichilemmomas } \\
\text { - papillomatous papules }\end{array}$ & $\begin{array}{l}\text { - Breast cancer } \\
\text { - Non-medullary thyroid } \\
\text { cancer } \\
\text { - Endometrial cancer } \\
\text { - Colorectal cancer } \\
\text { - Renal cell carcinoma } \\
\text { - Melanoma } \\
\text { - Brain tumors. }\end{array}$ \\
\hline $\begin{array}{l}\text { RAPADILINO syndrome } \\
\text { RECQL4 }\end{array}$ & $\begin{array}{l}\text { - Radial hypo-/aplasia } \\
\text { - Patellae hypo-/aplasia } \\
\text { - Cleft or highly arched palate } \\
\text { - Diarrhoea } \\
\text { - Dislocated joints } \\
\text { - Little size } \\
\text { - Limb Malformation } \\
\text { - Slender Nose } \\
\text { - Normal Intelligence }\end{array}$ & $\begin{array}{l}\text { - Osteosarcoma } \\
\text { - Lymphoma }\end{array}$ \\
\hline $\begin{array}{l}\text { Rothmund-Thomson } \\
\text { syndrome } \\
\text { RECQL4 }\end{array}$ & $\begin{array}{l}\text { - Poikiloderma } \\
\text { - Sparse hair, eyelashes, eyebrows } \\
\text { - Short stature } \\
\text { - Skeletal and dental abnormalities } \\
\text { - Cataract }\end{array}$ & $\begin{array}{l}\text { - Osteosarcoma } \\
\text { - Skin cancer }\end{array}$ \\
\hline $\begin{array}{l}\text { Rubinstein-Taybi syndrome } \\
\text { CREBBP } \\
\text { EP300 }\end{array}$ & $\begin{array}{l}\text { - Mental Retardation } \\
\text { - Postnatal growth deficiency and } \\
\text { Microcephaly } \\
\text { - Broad thumbs and halluces } \\
\text { - Dysmorphic facial features (highly arching } \\
\text { eyebrows, downslanting palpebral fissures, } \\
\text { broad nasal bridge, grimacing smile) }\end{array}$ & $\begin{array}{l}\text { - Brain tumours } \\
\text { (meningioma, } \\
\text { medulloblastoma, } \\
\text { neuroblastoma) } \\
\text { - Hematologic } \\
\text { malignancies } \\
\text { (leukaemia). }\end{array}$ \\
\hline
\end{tabular}




\section{Syndrome/ Gene}

Schinzel-Giedion syndrome SETBP1
Non-malignant clinical features

- Severe mental retardation

- Distinctive facial features (midface

retraction, choanal stenosis)

- Multiple congenital malformations

(skeletal, genitourinary, renal, cardiac)

Shwachman-Diamond syndrome

SBDS

- Exocrine pancreatic dysfunction

- Bony metaphyseal dysostosis

- Growth failure
- Hematologic abnormalities (single- or multi-lineage cytopenia, persistent or intermittent neutropenia)

Simpson-Golabi-Behmel
syndrome
GPC3
GPC4

Sotos syndrome NSD1

- Pre-/postnatal macrosomia macroglossia)

- Intellectual disability anomalies, organ defects, umbilical or

- Supernumerary nipples

- Overgrowth/ Macrocephaly

- Mild to severe intellectual impairment;
- Distinctive craniofacies (macrocephaly,

- Congenital abnormalities (structural brain diaphragmatic hernia, skeletal anomalies)

- Distinctive facial appearance (broad

forehead, sparse hair, downslanting

palpebral fissures, long chin)

- Advanced bone age

- Cardiac, Skeletal, Renal and/ or Cranial abnormalities

- Joint hyperlaxity

- Seizures.
Tuberous sclerosis

TSC1

TSC2

- Hamartomas in multiple organ systems

- Epilepsy

- Learning difficulties, behavioural problems, autism

- Abnormalities of the skin (hypomelanotic macules, angiofibromas)

- Brain anomalies (cortical dysplasia, subependymal nodules and subependymal giant cell astrocytomas [SEGAs])

- Kidney anomalies (angiomyolipomas,

cysts)

- Heart anomalies (rhabdomyomas, arrhythmias)

- Lymphangioleiomyomatosis of the lung

Von Hippel-Lindau syndrome

VHL
- Hemangioblastomas of the brain, spinal cord and retina

- Renal and pancreatic cysts
Malignancies reported

- Neuroepithelial tumours

- AML

- MDS
Embryonal tumours:

- Neuroblastoma

- Wilms tumour

- Hepatoblastoma

- Gonadoblastoma

- Hepatocellular carcinoma.
- ALL

- Neuroblastoma

- Hepatoblastoma

- Sacrococcygeal teratoma,

- Presacral ganglioma

- Small cell lung cancer
- Neuroendocrine tumours

- Glioma

- Malignant angiomyolipoma

- Renal cell carcinomas
- Clear Cell Renal carcinoma

- Pheochromocytoma

- Neuroendocrine tumours

- Endolymphatic sac tumours 


\begin{tabular}{|c|c|c|}
\hline Syndrome/ Gene & Non-malignant clinical features & Malignancies reported \\
\hline $\begin{array}{l}\text { WAGR syndrome } \\
\text { Deletion at } 11 \mathrm{p} 13 \\
\text { including WT1 and PAX6 }\end{array}$ & $\begin{array}{l}\text { - Aniridia } \\
\text { - Genitourinary abnormalities } \\
\text { - Mental retardation }\end{array}$ & - Wilms tumour \\
\hline $\begin{array}{l}\text { Weaver syndrome } \\
\text { EZH2 }\end{array}$ & $\begin{array}{l}\text { - Pre- and postnatal overgrowth } \\
\text { - Accelerated osseous maturation } \\
\text { - Development delay } \\
\text { - Characteristic craniofacial appearance } \\
\text { (broad forehead, ocular hypertelorism, wide } \\
\text { philtrum, micrognathia) } \\
\text { - Camptodactyly } \\
\text { - Umbilical hernia }\end{array}$ & - Neuroblastoma \\
\hline $\begin{array}{l}\text { Werner syndrome } \\
\text { WRN }\end{array}$ & $\begin{array}{l}\text { - Bilateral cataracts } \\
\text { - Premature greying and thinning of scalp } \\
\text { hair } \\
\text { - Scleroderma-like skin changes } \\
\text { - Short stature }\end{array}$ & $\begin{array}{l}\text { - Sarcomas (soft-tissue } \\
\text { sarcomas, } \\
\text { osteosarcomas) } \\
\text { - Very rare cancer types } \\
\text { in typical locations } \\
\text { (Acral lentiginous } \\
\text { melanomas) } \\
\text { - Melanomas } \\
\text { - Thyroid carcinomas. }\end{array}$ \\
\hline $\begin{array}{l}\text { Wiskott-Aldrich-syndrome } \\
\text { WAS }\end{array}$ & $\begin{array}{l}\text { - Immune deficiency } \\
\text { - Inflammatory disorders (eczema) } \\
\text { - Microthrombocytopenia } \\
\text { - Autoimmune disorders }\end{array}$ & - Lymphoma \\
\hline $\begin{array}{l}\text { Xeroderma pigmentosum } \\
\text { ERCC4 } \\
\text { DDB2, ERCC1, ERCC2, } \\
\text { ERCC3, ERCC5, POLH, XPA, } \\
\text { or XPC }\end{array}$ & $\begin{array}{l}\text { - Increased sun sensitivity } \\
\text { - Freckle-like pigmentation of the face } \\
\text { - Sunlight-induced ocular involvement } \\
\text { (photophobia, keratitis, atrophy of the skin } \\
\text { of the lids) }\end{array}$ & $\begin{array}{l}\text { - Malignant skin } \\
\text { tumour }\end{array}$ \\
\hline
\end{tabular}

\section{Supplementary Files}

This is a list of supplementary files associated with this preprint. Click to download.

- PERCEPTFORM.docx 